\title{
Urinary Cyclophilin: A New Marker for Diabetic Nephropathy
}

\author{
ENGY A. EBRAHIM, M.D.; ENAAM S. ABD EL-BAR, M.D.; SHEREEN A. ABD EL-SALAM, M.D. and \\ HEND M. EL-ZAREEF, M.Sc.
}

The Department of Internal Medicine, Faculty of Medicine, Tanta University, Tanta, Egypt

\begin{abstract}
Background: Nephropathy is a significant cause of morbidity and mortality in patients with Diabetes Mellitus (DM). The condition is characterized by persistent albuminuria and may be decline in the Glomerular Filtration Rate (GFR). Urinary cyclophillin A has been proposed as a simple, accurate and rapid endogenous marker for DN.
\end{abstract}

Aim of Study: To assess the value of urinary cyclophillin A anew marker of diabetic nephropathy.

Subjects and Methods: Group I: 60 patients with type 2 diabetes mellitus which will be subdivided into: (A) 30 diabetic patients with diabetic nephropathy. (B) 30 diabetic patients without diabetic nephropathy. Group II: 30 healthy persons as a control group.

Results: There was significance association between urinary cyclophillin A and serum creatinine, blood urea, 24 $\mathrm{h}$ protein collection and ACR.

Urinary cyclophilin A found higher in diabetic nephropathy patients than diabetic patients without nephropathy so it is a new marker for diabetic nephropathy.

Conclusion: The results of this study suggest that urinary cyclophillin A new marker for diabetic nephropathy.

Key Words: Type 2 diabetes mellitus - Diabetic nephropathy - Urinary cyclophillin A.

\section{Introduction}

DIABETES is a group of metabolic diseases characterized by hyperglycemia resulting from defects in insulin secretion, insulin action, or both. The chronic hyperglycemia of diabetes is associated with long-term damage, dysfunction, and failure of different organs, especially the eyes, kidneys, nerves, heart, and blood vessels [1].

Correspondence to: Dr. Engy A. Ebrahim, The Department of Internal Medicine, Faculty of Medicine, Tanta University, Tanta, Egypt
Type 2 Diabetes Mellitus (DM) is the most common cause of end-stage renal disease [2]

The Joint committee of diabetic nephropathy is trying to develop a new classification of Diabetic Nephropathy (DN) combining both glomerular filtration rate and albuminuria systems [3]. There are several markers to predict onset and progression of DN. Albuminuria is the most commonly used marker. However, it lacks both sensitivity and specificity to detect early stage of DN [4].

Urinary Cyclophilin A (CypA) is an $18-\mathrm{kDa}$ protein with ubiquitous characteristics. It is mostly distributed in the cytoplasm and facilitates protein folding and protein trafficking. It also acts as a cellular receptor for cyclosporine A (CsA) [5] .

Secreted Cyp A (sCyp A) was reported to be correlated with Cardiovascular Disease (CVD), asthma, Rheumatoid Arthritis (RA), liver injury and inflammatory diseases [6]. It was also detected in diabetic patients' plasma and was shown to be secreted by monocytes in response to hyperglycemia [7].

\section{Subjects and Methods}

This study will be done from February 2016 to September 2016 at Tanta Hospitals ". An informed consent will be taken from all participants and the privacy of the data will be greatly considered.

The study will be carried out on two groups:

Group I: 60 patients with type 2 diabetes mellitus which will be subdivided into:

A- 30 diabetic patients with diabetic nephropathy.

B- 30 diabetic patients without diabetic nephropathy. 
Group II: 30 healthy persons as a control group.

\section{Study design:}

It is cross sectional observational study.

\section{Exclusion criteria:}

- Patients suffer from infectious disease.

- Patients suffer from chronic inflammatory disease.

- Patients suffer from liver disease or malignancy.

- Pregnant women.

All patients included in the study will be subjected to:

- Through history taking.

- Complete clinical examination including: Body Mass Index (BMI) calculation.

- Laboratory investigations including:

- Blood urea and serum creatinine.

- Fasting and 2 hour post prandial blood glucose.

- HB A1C.

- Urine Albumin/Creatinine ratio.

- Lipid profile (Triglycerides, Cholesterol, LDL and HDL).

- Estimated glomerular filtration rate.

- Erythrocyte Sedimentation Rate (ESR).

- 24 hours urine collection for proteins.

- Specific investigation: Estimation of urinary cyclophilin A by ELIZA.

- Imaging including: Ultra sonography abdomen, pelvis.

\section{Statistical analysis:}

For quantitative data, the Shapiro-Wilk test for normality was performed. For normally distributed data, values were expressed as mean \pm standard deviation and independent samples $t$-test was performed for comparison between two groups while one way ANOVA was used for comparison between more than two groups. For data that were not normally distributed, median and interquartile range (expressed as 25 th-75 th percentiles) were calculated and Kruskal Wallis test and Spearman's rank-order correlation were used. For qualitative data, Pearson's Chi square test was used to examine association between two variables. Significance was adopted at $p<0.05$ for interpretation of test results.

\section{Results}

\section{Demographic data of all studied groups:}

After Ethical Committee approval from Research Center in Tanta University and written consent from all subjects, this study was conducted in the Internal Medicine Department. The patients were recruited for the study on the basis of standard clinical and laboratory criteria for diagnosis of diabetes and kidney disease. They were selected from in-patients and out-patients clinics of Internal Medicine Department, Tanta University Hospital. This study was conducted on 90 subjects classified as follows:

Group IA: 30 diabetic patients with diabetic nephropathy. Their age ranged from 42 to 64 years with a mean value 58.3.

18 patients were males and 12 were females with a male to female ratio of 1.5:1.

Group IB: 30 diabetic patients without diabetic nephropathy. Their age ranged from 44 to 69 years with a mean value 56.7 .

16 patients were males and 14 were females with a male to female ratio of 1.14:1.

Group II: 30 apparently healthy volunteers (as a control group), their age ranged from 43 to 68 years with a mean value 55.5. 15 of them were males and 15 were females with a male to female ratio of 1:1.

Table (1): Age, sex and BMI in the studied groups.

\begin{tabular}{|c|c|c|c|c|c|}
\hline & \multicolumn{3}{|c|}{ Group } & \multicolumn{2}{|c|}{$\begin{array}{c}\text { Tests of } \\
\text { significance }\end{array}$} \\
\hline & $\begin{array}{c}\text { Group } \\
\text { IA }\end{array}$ & $\begin{array}{c}\text { Group } \\
\text { IB }\end{array}$ & $\begin{array}{c}\text { Group } \\
\text { II }\end{array}$ & $\begin{array}{c}\text { Test } \\
\text { statistic }\end{array}$ & $p$ \\
\hline \multicolumn{6}{|c|}{ Age: } \\
\hline Minimum-maximum & $42-64$ & $44-69$ & $43-68$ & $\mathrm{~F}=$ & 0.291 \\
\hline Mean & 58.3 & 56.7 & 55.5 & 1.253 & \\
\hline Standard Deviation & 6.0 & 7.7 & 6.7 & & \\
\hline \multicolumn{6}{|l|}{ Sex: } \\
\hline \multicolumn{6}{|l|}{ - Male: } \\
\hline $\mathrm{N}$ & 18 & 16 & 15 & $\chi \mathrm{ChS}=$ & 0.731 \\
\hline$\%$ & 60.0 & 53.3 & 50.0 & 0.627 & \\
\hline \multicolumn{6}{|l|}{ - Female: } \\
\hline $\mathrm{N}$ & 12 & 14 & 15 & & \\
\hline$\%$ & 40.0 & 46.7 & 50.0 & & \\
\hline \multicolumn{6}{|l|}{ BMI: } \\
\hline Minimum-maximum & $21-35$ & $19-35$ & $18-28$ & \multicolumn{2}{|c|}{ FWelch $=<0.001 *$} \\
\hline Mean & 29 & 28 & 23 & 31.334 & \\
\hline Standard Deviation & 3 & 5 & 3 & & \\
\hline
\end{tabular}

Post-hoc comparisons (Tukey's test). 
Table (2): Urinary Cyclophilin A level in the studied groups.

\begin{tabular}{lllllll}
\hline & \multicolumn{3}{c}{ Group } & & \multicolumn{2}{c}{$\begin{array}{c}\text { Tests of } \\
\text { significance }\end{array}$} \\
\cline { 2 - 4 } $\begin{array}{l}\text { Urinary } \\
\text { Cyclophilin A }\end{array}$ & $\begin{array}{c}\text { Group } \\
\text { IA }\end{array}$ & $\begin{array}{c}\text { Group } \\
\text { IB }\end{array}$ & $\begin{array}{c}\text { Group } \\
\text { II }\end{array}$ & $\begin{array}{c}\text { Test } \\
\text { statistic }\end{array}$ & $p$ \\
\hline Minimum-maximum & $9-19$ & $3-6$ & $0-2$ & & ZKW= & $<0.001^{*}$ \\
Median & 10 & 4 & 2 & & 79.140 & \\
IQR & $10-12$ & $3-5$ & $1-2$ & & \\
Mean ranks & 75.50 & 45.50 & 15.50 & & \\
\hline
\end{tabular}

Pair-wise comparison (between group comparison).

Dunn-Bonferroni test

Group IA - Group IB

$p<0.001 *$ Group IA-Group II.

$p<0.001 *$ Group IB-Group II.

$p<0.001 *$.

Table (3): Correlations between Urinary Cyclophilin A and blood urea, serum creatinine, albumin/creatinine ratio, estimated GFR and $24 \mathrm{~h}$ protein in the studied groups.

\begin{tabular}{|c|c|c|c|c|}
\hline & \multicolumn{4}{|c|}{ Urinary Cyclophilin A } \\
\hline & $\begin{array}{c}\text { All } \\
\text { participants }\end{array}$ & $\begin{array}{l}\text { Group } \\
\text { IA }\end{array}$ & $\begin{array}{l}\text { Group } \\
\text { IB }\end{array}$ & $\begin{array}{c}\text { Group } \\
\text { II }\end{array}$ \\
\hline \multicolumn{5}{|c|}{ Blood urea: } \\
\hline$r_{\mathrm{s}}$ & 0.746 & 0.878 & 0.080 & -0.141 \\
\hline$p$ & $<0.001^{*}$ & $<0.001 *$ & 0.674 & 0.458 \\
\hline \multicolumn{5}{|c|}{ Serum creatinine: } \\
\hline$r_{\mathrm{s}}$ & 0.619 & 0.837 & 0.400 & -0.088 \\
\hline$p$ & $<0.001^{*}$ & $<0.001^{*}$ & $0.028^{*}$ & 0.644 \\
\hline \multicolumn{5}{|c|}{ Albumin/creatinine ratio: } \\
\hline$r_{\mathrm{s}}$ & 0.627 & 0.921 & 0.681 & 0.123 \\
\hline$p$ & $<0.001^{*}$ & $<0.001^{*}$ & $<0.001^{*}$ & 0.518 \\
\hline \multicolumn{5}{|c|}{$\begin{array}{l}\text { Estimated glomerular } \\
\text { filtration rate: }\end{array}$} \\
\hline$r_{\mathrm{s}}$ & $-0.705-$ & $-0.716-$ & -0.565 & 0.342 \\
\hline$p$ & $<0.001 *$ & $<0.001 *$ & $0.001^{*}$ & 0.064 \\
\hline$p$ & $<0.001 *$ & 0.939 & 0.064 & 0.138 \\
\hline \multicolumn{5}{|c|}{24 protein: } \\
\hline$r_{\mathrm{s}}$ & 0.743 & 0.949 & 0.987 & 0.782 \\
\hline$p$ & $<0.001 *$ & $<0.001 *$ & $<0.001 *$ & $<0.001^{*}$ \\
\hline
\end{tabular}

Table (4): Correlations between Urinary Cyclophilin A and fasting blood glucose, $2 \mathrm{~h}$ postprandial blood glucose, $\mathrm{HbA} 1 \mathrm{c}$ and ESR in the studied groups.

\begin{tabular}{lllll}
\hline & \multicolumn{4}{c}{ Urinary Cyclophilin A } \\
\cline { 2 - 5 } & \multicolumn{1}{c}{ All } & Group & Group & Group \\
& participants & IA & IB & II \\
\hline Fasting blood glucose: & & & & \\
$\quad r_{\mathrm{s}}$ & 0.697 & 0.498 & 0.331 & -0.072 \\
$p$ & $<0.001^{*}$ & $0.005^{*}$ & 0.074 & 0.704 \\
2h Postprandial & & & & \\
blood glucose: & & & & \\
$r_{\mathrm{s}}$ & 0.732 & 0.519 & 0.048 & 0.364 \\
$p$ & $<0.001 *$ & $0.003^{*}$ & 0.802 & $0.048^{*}$ \\
HbAlc: & & & & \\
$r_{\mathrm{s}}$ & 0.778 & 0.040 & 0.122 & \\
$p$ & $<0.001 *$ & 0.834 & 0.521 & \\
ESR: & & & & \\
$r_{\mathrm{s}}$ & 0.547 & 0.015 & 0.343 & 0.277 \\
$p$ & $<0.001 *$ & 0.939 & 0.064 & 0.138 \\
\hline
\end{tabular}

\section{Discussion}

Diabetes mellitus is a group of physiological dysfunctions characterized by hyperglycemia resulting directly from insulin resistance, inadequate insulin secretion, or excessive glucagon secretion. Type 2 DM (non-insulin dependent DM) is the most common form of DM characterized by hyperglycemia, insulin resistance, and relative insulin deficiency [8] .

Type 2 DM results from interaction between genetic, environmental and behavioral risk factors.

Patients with diabetes mellitus are more vulnerable to various forms of both short-and longterm complications, which often lead to their premature death. This tendency of increased morbidity and mortality is seen in patients with type $2 \mathrm{DM}$ [9].

Diabetic nephropathy represents the major cause of End-Stage Renal Disease (ESRD). One of the hallmarks of diabetic nephropathy is the development of proteinuria, which is usually followed by a progressive decline in renal function. The development of diabetic nephropathy is also a major risk factor for cardiovascular disease [10]

From an epidemiological, pathophysiological and clinical perspective, hypertension and poor glycaemic control are usually associated with diabetic nephropathy [11,12] .

The aim of the present study to assess the value of estimation Urinary Cyclophilin A as a new marker for diabetic nephropathy.

This study was conducted in the Internal Medicine Department. The patients were recruited for the study on the basis of standard clinical and laboratory criteria for diagnosis of diabetes and diabetic nephrorathy. They were selected from inpatients and out-patients clinics of Internal Medicine Departments, Tanta University Hospital.

An informed consent will be taken from all participants and the privacy of the data will be greatly considered.

In this work it was found that there was no significance difference among all studied groups as regard age and sex, however it was observed that the percentage of male patients with diabetic nephropathy was increased as compared to that of female patients in the same group.

This was in agreement with Rossouw et al., (2002) [13] who reported that men are more likely 
to develop coronary artery disease, stroke, microvasculopathy and other cardiovascular manifestation of atherosclerosis. This is due to the protective effect of female hormones (estrogens) so that heart disease risk for women rises dramatically after menopause.

Also Michelle, [14] reported that the incidence of coronary artery disease and kidney disease increases with age, men older than 45 and women older than 55 (or younger if they have premature menopause) are at greater risk of heart disease.

In this study, we propose that urinary CypA can be used as an early marker for identifying DN with a high sensitivity and high diagnostic power. Detection of urinary CypA is also very convenient because it is noninvasive. Now that urinary CypA appears to be capable of identifying DN in the silent stage.

In an extensive review conducted by Lee et al., urinary CypA was not mentioned as a potential biomarker for DN [15].

This is the first study to use urinary CypA in early DN detection. CypA was mostly studied in CVD and lung or liver injury [5] .

Asthma and RA are associated with this new marker [16]

The present investigation is the 3 rd study to identify a correlation between CypA and DM. Furthermore, this is the 1 st study to verify the association between urinary CypA and DN.

\section{Conclusions:}

- Urinary cyclophilin A was significantly increased in diabetic patients with diabetic nephropathy than diabetic patients without nephropathy and normal (control groups).

- Urinary cyclophillin A is useful practical non invasive tool for early detection of diabetic nephropathy.

\section{References}

1- GENUTH S., ALBERTI K.G., BENNETT P., et al.: Expert Committee on the Diagnosis and Classification of Diabetes Mellitus. Follow-up report on the diagnosis of diabetes mellitus. Diabetes Care, 26: 3160-7, 2003.

2- ARORA M.K. and SINGH U.K.: Molecular mechanisms in the pathogenesis of diabetic nephropathy: An update. Vascul. Pharmacol., 58: 259-71, 2013.
3- HANEDA M., UTSUNOMIYA K., KOYA D., et al.: A new classification of diabetic nephropathy: A report from Joint Committee on Diabetic Nephropathy. J. Diabetes Invest., 6: 242-6, 2015.

4- HALIMI J.M.: The emerging concept of chronic kidney disease without clinical proteinuria in diabetic patients. Diabetes Metab., 38: 291-7, 2012.

5- DEAR J.W., SIMPSON K.J., NICOLAI M.P., et al.: Cyclophilin A is a damage-associated molecular pattern molecule that mediates acetaminophen-induced liver injury. J. Immunol., 187: 3347-52, 2011.

6- NIGRO P., POMPILIO G. and CAPOGROSSI M.C.: Cyclophilin A: A key player for human disease. Cell Death, 4: 888, 2013.

7- RAMACHANDRAN S., VENUGOPAL A., KUTTY V.R., et al.: Plasma level of cyclophilin A is increased in patients with type 2 diabetes mellitus and suggests presence of vascular disease. Cardiovasc. Diabetol., 13: 38, 2014.

8- MAITRA A. and ABBAS A.K.: Endocrine system. In: Kumar V., Fausto N., Abbas A.K. (eds). Robbins and Cotran Pathologic basis of disease ( 7 th ed). Philadelphia, Saunders, 1156-226, 2005.

9- CHEN L., MAGLIANO D.J. and ZIMMET P.Z.: The worldwide epidemiology of type 2 diabetes mellitus: present and future perspectives. Nature reviews endocrinology. Available at: www.nature.com/uidfinder (Accessed 22nd December), 2011.

10- RITZ E. and ORTH S.R.: Nephropathy in patients with type 2 diabetes mellitus. N. Engl. J. Med., 341: 1127-33, 2013.

11-ADLER A.I.: Association of systolic blood pressure with macrovascular and microvascular complications of type 2 diabetes (UKPDS 36): Prospective observational study. B.M.J., 321: 412-9, 2012.

12- STRATTON I.M.: Association of glycaemia with macrovascular and microvascular complications of type 2 diabetes (UKPDS 35): Prospective observational study. B.M.J., 321: 405-12, 2012.

13-ROSSOUW J.E., ANDERSON G.L. and PRENTICE R.L.: Writing Group for the women's Health Initiative investigations. Risk and benefits of estrogen plus progestin in healthy postmenopausal women: Principal results from the women's Health Initiative Randomized Controlled Trial J.A.M.A., 288: 321-33, 2002.

14- MICHELLE BADASH M.S.: Conditions in Depth: Coronary Artery Disease (CAD) and Angina. In: Heart disease: A textbook of cardiovascular medicine. WB Saunders. 890-905, 2001

15- LEE S.Y. and CHOI M.E.: Urinary biomarkers for early diabetic nephropathy: beyond albuminuria. Pediatr. Nephrol., 25: 1063-75, 2014.

16- RYFFEL B., WOERLY G., GREINER B., et al.: Distribution of the cyclosporine binding protein cyclophilin in human tissues. Immunology, 72: 399-404, 2013. 


\section{السيليكوفيلين آ البولى كدلالة جليدة لإعتلال الكلى السكرى}

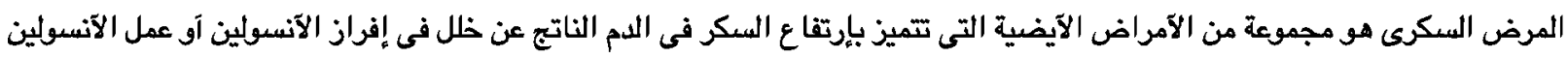

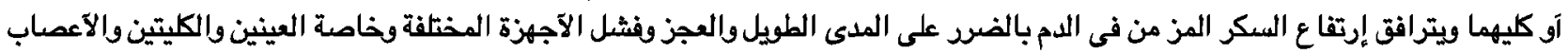

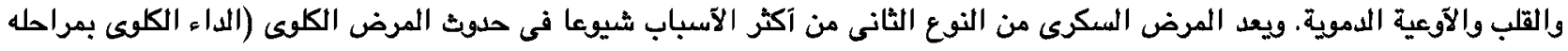

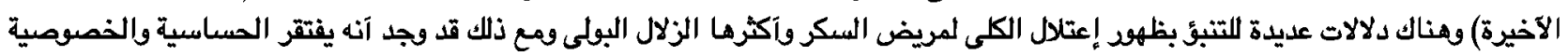

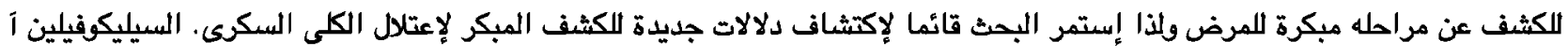

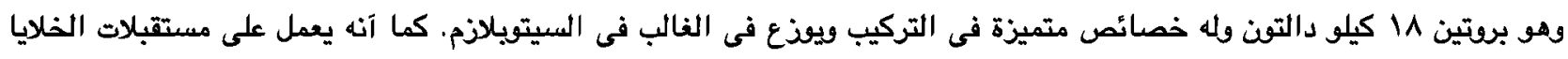

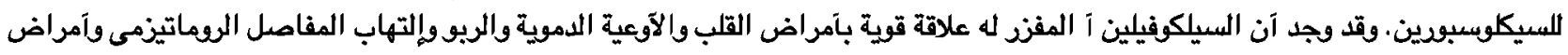

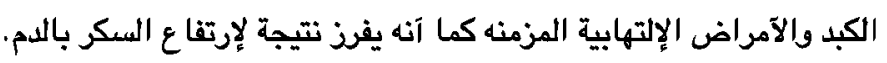

$$
\begin{aligned}
& \text { الهدف من البحث: قيمة دراسة تقدير السيلكوفيلين آ البولى كدلالة جديدة للإعتلال الكلى السكرى. }
\end{aligned}
$$

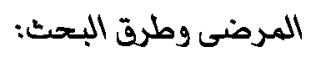

$$
\begin{aligned}
& \text { تم إجراء هذا البحث على مجموعتين من المرضي: }
\end{aligned}
$$

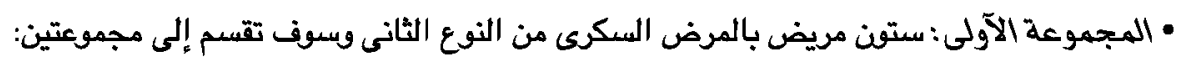

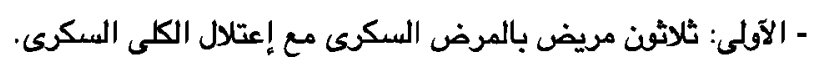

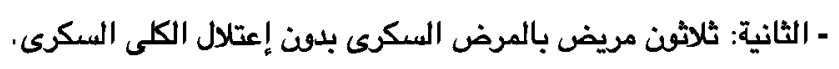

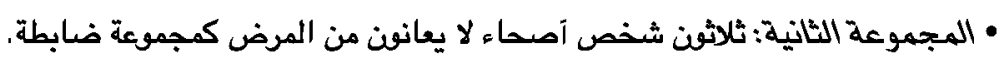

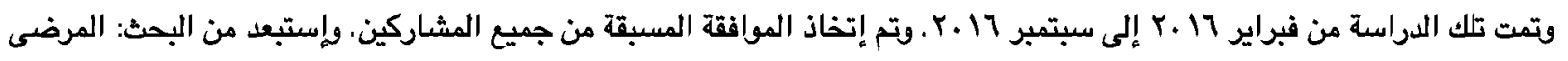

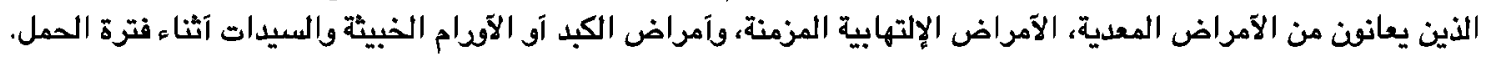

النتائج: كان هناك إرتباط كبير بين مرض البول السكرى والمضاعفات الرئيسية لدى مرضى السكرى: الإعتلال الكلوى، إعتلال الشبكية، الإعتلال العصبى والآمراض القلبية الوعائية.

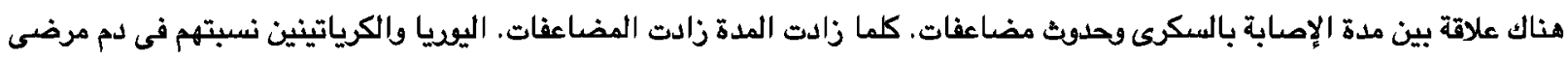

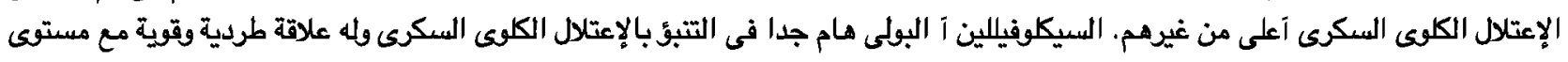

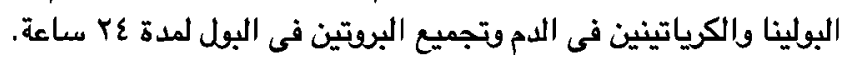

